\title{
EXPERIMENTAL STUDY ON THE DURABILITY OF HOTMIX COLD LAID ASBUTON AS ASPHALT POROUS WITH CANTABRO TEST
}

\author{
Sri Gusty ${ }^{1}$, M.W. Tjaronge ${ }^{2}$, Nur Ali $^{3}$ and Rudy Djamaluddin ${ }^{4}$
}

\begin{abstract}
Natural Asphalt from Buton Island can be used as a substitute material for petroleum asphalt, which is known as asbuton. Asphalt Buton (Asbuton) is natural asphalt that contained in the rock deposit located in Buton Island and surrounding areas. Natural asphalt at the Buton Island (asbuton) has a huge deposit for a binder in asphalt mixture use. Many attempts have been carried out to improve the utilization of Buton asphalt as a binder in asphalt pavement road. One of them is the technology development of Buton asphalt pre-mix by adding fluxing materials (modifiers) that serves to soften the bitumen asbuton into the appropriate characteristics as a binder in the asphalt mixture. By adding the fluxing materials, asphalt mixture can be durable even spread and compacted at the cold temperature. This mixture is very useful in areas that have limited asphalt mixture production (AMP) such as in the isolated and small islands in Indonesia. In the pre-mixed Buton asphalt, the mixing is produced on the manufacturing asphalt mixing plant (AMP). After mixing, it can be stored or packaged, while rolling and compaction procces in the field can be performed at cold temperature. The test results of cantabro with the same level of 5.5\% BGA and 3.5\% flux oil showed that the mixture satisfy the requirements of the asphalt porous mixture according to REAM (Road Engineering Association of Malaysia), which is maximum of $20 \%$.
\end{abstract}

Keywords: Asphalt Porous, Cantabro Test, Asphalt Composition, BGA

\section{INTRODUCTION}

One of the use of natural asphalt from Buton Island is to be a subtitute material for petroleum asphalt . By optimizing the utilization of Buton asphalt product, the petroleum bitumen consumption can be reduced, thus can sustain the national and regional road infrastructure development. There is a large resource of natural rock asphalt (sedimentary rock containing of high hydrocarbon substances) in South Buton Island, Southeast Sulawesi in Indonesia. The deposit of Buton rock asphalt resource are approximately 60.991.554.38 tons (24.352.883.07 barrel oil equivalent) (Suryana.A. 2003). Buton granular asphalt (BGA) is produced by crushing the rock asphalt and has size between $1.18 \mathrm{~mm}$ to $9.5 \mathrm{~mm}$. There were many researches and developments have been carried out to optimize the utilization of Buton asphalt and its product variation in the wearing course of pavement (Firdaus et al., 2014), (Furqon et al., 2009), (Gaus et al., 2014), (Nur Ali et al., 2011), and (Tjaronge et al., 2013). Asphalt mixing plant (AMP) is required to produce hot mix asphalt (HMA), but there are many distant and remote areas without AMP. The required of hot temperature and AMP introduce an obstacle in rolling and compaction of asphalt mixture that has prevented its utilization in paving construction at the remote area. HRA (Hot Rolled Asphalt) is rolled and compacted at temperatures between $120^{\circ} \mathrm{C}-160^{\circ} \mathrm{C}$. The high temperature maintains the bitumen viscosity and ensures the workability of asphalt mixture. The decreasing temperature of mixture creates the bitumen within the asphalt mixture harder, reduce the workability and resulting a poorly compacted asphalt mixture. The inadequate compaction of asphalt mixture reduces the quality of pavement construction work. This paper is part of an ongoing study to investigate the suitability of bitumen within BGA to produce hotmix and compact it in cold temperature between $50^{\circ} \mathrm{C}$. Application of hot mix cold laid containing BGA as surface in the pavement structure presents available alternative to pavement constructed using HRA. Mixture containing BGA and aggregates was modified by flux oil in order to maintain its workability.

The addition of flux oil with the same level of $3.5 \%$ as added material on porous asphalt mixture using 5,5\% BGA, after compaction in cold temperatures. The obtained contabro test result with porosity values meet the REAM specifications.

\footnotetext{
${ }^{1}$ Doctoral Course Student, Civil Engineering Department, Hasanuddin University, Makassar, 90245, INDONESIA

${ }^{2}$ Professor, Civil Engineering Department, Hasanuddin University, Makassar, 90245, INDONESIA

${ }^{3}$ Associate Professor, Civil Engineering Department, Hasanuddin University, Makassar, 90245, INDONESIA

${ }^{4}$ Associate Professor, Architecture Engineering Department, Hasanuddin University, Makassar, 90245, INDONESIA
} 


\section{MATERIALS AND METHODS}

\section{Some properties of Buton Granural Asphalt (BGA)}

BGA that used in this research is from Lawele area and produced by the national asphalt Buton plant, it is available in the market. Contain of $25,47 \%$ bitumen, which means it contains of $75 \%$ minerals. BGA has grains smaller than 9,5 $\mathrm{mm}$ and with a water content of $0,81 \%$. BGA properties are shows in Table 1 .

Table 1 Some properties of buton granural asphalt

\begin{tabular}{cc}
\hline Properties & Value \\
\hline Bitumen content, $\%$ & 25,47 \\
Passing sieves $3 / 8 "(9,5 \mathrm{~mm}), \%$ & 100 \\
Water content, $\%$ & 0,81 \\
Asphalt mineral level, $\%$ & 74,53 \\
Penetration of bitumen, $(\mathrm{dmm})$ & 36 \\
Melting point of bitumen, ${ }^{\circ} \mathrm{C}$ & 59 \\
Flash point before extract, ${ }^{\circ} \mathrm{C}$ & 198 \\
\hline
\end{tabular}

\section{Physical Properties of Aggregates}

Table 2 shows some physical properties of fine and coarse aggregates, respectively. Crused river stone and river sand were used as coarse and fine aggregates, respectively. In this study, aggregates testing were conducted prior the mix design and analysis.

Table 2 Some properties of aggregates

\begin{tabular}{cc}
\hline Parameter & Value \\
\hline Coarse Aggregate & 2.55 \\
Bulk Density & 2.61 \\
SSD Density & 2.72 \\
Apparent Density & 22.64 \\
Abrasion (\%) & 8.21 \\
Particle flat and oval (\%) & 2.37 \\
Absorption (\%) & \\
Fine Aggregate & 2.56 \\
Bulk Density & 2.61 \\
SSD Density & 2.70 \\
Apparent Density & 1.89 \\
Absorption (\%) & 83.9 \\
Sand Equivalent Value (\%) & \\
Filler & 2.55 \\
Bulk Density & 2.61 \\
SSD Density & 2.71 \\
Apparent Density & 2.29 \\
Absorption (\%) & 0.66 \\
Sand Equivalent Value (\%) &
\end{tabular}

\section{Combined aggregate gradation in hot mix design}

Table 3 shows grain size distribution used in this study. The mineral within BGA was taken into account when analysis the mixture composition and grain size distribution.

Table 3 Gradation size distribution in this study

\begin{tabular}{cc}
\hline Sieve & Weight $(\mathrm{Gr})$ \\
\hline $1 / 2^{\prime}(14 \mathrm{~mm})$ & 28,85 \\
$3 / 8^{\prime}(10 \mathrm{~mm})$ & 481,50 \\
No.4 $(5 \mathrm{~mm})$ & 430,52 \\
\hline Bitumen BGA & 66,00 \\
Mineral BGA & 193,13 \\
\hline
\end{tabular}




\section{Mixture Preparation}

The stages of mix the aggregates, modifier and BGA are as follow :

1. Before adding to the mixture, aggregates were heated to $170^{\circ} \mathrm{C}$ for a period of approximately 1800 seconds. The weight of each sample was $1.200 \mathrm{gr}$.

2. The hot modifier was $3,5 \%$ by weight of aggregates content in all mixtures. Without heated, hot modifier was added in the mixture of aggregates.

3. The mixing of aggregates and modifier were blended at a temperature of $130 \pm 5^{\circ} \mathrm{C}$ for around 60 seconds proir to blending with BGA.

4. BGA was added into the mixture and blended with other materials for about 120 seconds.

Table 4 Compaction temperature at each storing and compaction time

\begin{tabular}{cc}
\hline $\begin{array}{c}\text { Storing and } \\
\text { compaction time }\end{array}$ & $0(4$ hours $)$ \\
\hline $\begin{array}{c}\text { Compaction } \\
\text { temperature }\left({ }^{0} \mathrm{C}\right)\end{array}$ & 50 \\
\hline
\end{tabular}

\section{Asphalt Porous}

Terms and conditions of porous asphalt mix can be sees in Table 5 below.

Table 5 Some properties of Asphalt Porous

\begin{tabular}{lcc}
\hline No. & Planning criteria & Value \\
\hline 1 & Test Cantabro Loss $(\%)$ & Maks. 20 \\
2 & Test flow asphalt down $(\%)$ & Maks. 0,3 \\
3 & Void content in the mix $(\mathrm{VIM} \%)$ & $18-25$ \\
4 & Marshall stability $(\mathrm{Kg})$ & Min. 350 \\
5 & Fatigue marshall $(\mathrm{mm})$ & $2-4$ \\
6 & Marshall Quotient $(\mathrm{kg} / \mathrm{mm})$ & Min. 200 \\
7 & Number of collisions field & 50 \\
\hline
\end{tabular}

\section{RESULTS AND DISCUSSION}

\section{Cantabro Test}

Cantabro testing was applied to determine the weight loss of the specimen after the abrasion test with the Los Angeles Machine. The test was carried out under optimum levels of porous asphalt mixture. This is to determine the durability of porous asphalt mixture. The test results cantabro obtained the results as shown in Table 6 .

Table 6 Testing Result Cantabro

\begin{tabular}{|c|c|c|c|c|c|c|c|c|}
\hline \multirow{3}{*}{ NO. } & \multirow{3}{*}{$\begin{array}{c}\text { Flux Oil } \\
\text { Contennt of } \\
\text { Flux Oil }\end{array}$} & \multicolumn{3}{|c|}{ BGA } & \multirow{2}{*}{$\begin{array}{l}\text { Sample } \\
\text { Weight }\end{array}$} & \multirow{3}{*}{ Porosity } & \multicolumn{2}{|c|}{ Test Cantabro } \\
\hline & & Content & Weight & Weight & & & Sample Weight & Abrasion \\
\hline & & BGA & Mineral & Bitumen & Start & & Finish & Value \\
\hline & $(\%)$ & $(\%)$ & (Gram) & (Gram) & (Gram) & $(\%)$ & (Gram) & $(\%)$ \\
\hline 1 & 3,5 & 5,5 & 193,13 & 66 & 1218 & 25,73 & 1085 & 10,92 \\
\hline 2 & 3,5 & 5,5 & 193,13 & 66 & 1210 & 26,22 & 1141 & 5,70 \\
\hline 3 & 3,5 & 5,5 & 193,13 & 66 & 1233 & 24,81 & 1209 & 1,95 \\
\hline 4 & 3,5 & 5,5 & 193,13 & 66 & 1193 & 27,65 & 1167 & 2,18 \\
\hline 5 & 3,5 & 5,5 & 193,13 & 66 & 1212 & 26,51 & 1187 & 2,06 \\
\hline 6 & 3,5 & 5,5 & 193,13 & 66 & 1194 & 27,60 & 1170 & 2,01 \\
\hline
\end{tabular}




\section{Relationship between BGA and Modifier}

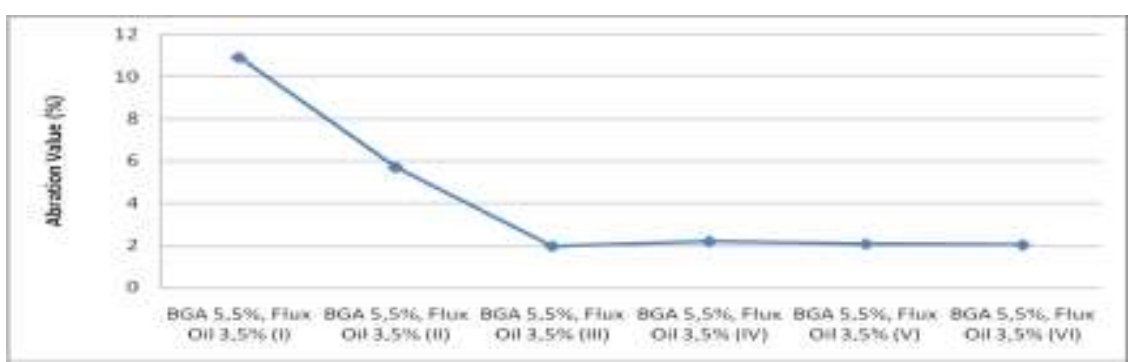

Fig. 1 Caption of relationship between BGA and abration value

\section{CONCLUSIONS}

In this paper showa that a mixture made of BGA with hot modifier could be compacted at temperature of $50^{\circ} \mathrm{C}$. Cantabro testing using Los Angeles Machine and the result can be seen in Table 6. It shows that the cantabro test result for the mixture BGA 5,5\% with flux oil 3,5\% using 6 samples showed that the mixture of asphalt porous has a level of good durability and fullfil the requirement. This is evidenced by the percentage of weight loss average, which is $4,14 \%$. A lower Cantabro's value indicates that the mixture will lose little weight so it has a high resistance in the field conditions such as weather, temperature and acidity of rainwater. The different percentage of weight loss caused by the thickness of the bitumen that covering the different aggregate when it was mixing together.

\section{REFERENCES}

A. Gaus, Tjaronge, M.W, N. Aland R. Djamaluddin. 2014. Experimental Study on Characteristics of Asphalt Concrete Bearing Coarse (AC BC) Mixture Using Buton Granular Asphalt (BGA). International Journal of Applied Engineering Research. 9(22): 18037-18045.

Budiamin, Tjaronge, M.W, Sumarni Hamid Ali, and R. Djamaluddin. 2015. Mechanical Characteristics Of Hotmix Cold Laid Containing Buton Granural Asphalt (BGA) and Flux Oil as Wearing Course. ARPN Journal of Engineering and Applied Sciences ISSN 1819-6608.

Kemas A. Zamhari, Madi Hermadi and Mohamed H. Ali. 2014. Comparing the Performance of Granural and Extracted Binder from Buton Rock Asphalt. International Journal of Pavement Research and Technology. 7(1).

N. Ali, M.W. Tjaronge, L. Samang and M.I. Ramli. 2011. Experimental Study on Effects of Flood Puddle to Durability of Asphaltic Concrete Containing Refined Butonic Asphalt. Journal of the Eastern Asia Society for Transportation Studies. 9: 1364-1375.

Road Engineering Association Of Malaysia (REAM, 2008), Specification For Porous Asphalt.

Suryana. A. 2003. Inventory on Solid Bitumen Sediment Using 'Outcrop Drilling' in Southern Buton Region, Buton Regency, Province Southeast Sulawesi, Colloquium on Result Activities of Mineral Resources Inventory. - DIM, the TA.2003, Directorate Mineral.

Tjaronge. M.W and Rita Irmawaty. 2013. Influence of Water Immersion on Physical Properties of Porous Asphalt Containing Liquid Asbuton as Bituminous Asphalt Binder. Proceedings of 3rd International conference and Sustainable Construction Material and Technologies-SCTM, Kyoto, Japan. 